\title{
Causes of the skewed sex ratio in the Critically Endangered Formosa landlocked salmon of Taiwan
}

\author{
Te-Hua Hsu' ${ }^{1}$, Chia-Yang Chen ${ }^{2}$, Jin-Chywan Gwo ${ }^{1, *}$ \\ ${ }^{1}$ Department of Aquaculture, Taiwan National Ocean University, No. 2 Pei-Ning Road, Keelung 20224, Taiwan \\ ${ }^{2}$ Institute of Environmental Health, College of Public Health, National Taiwan University, 17 Hsu-Chou Road, Taipei 10055, Taiwan
}

\begin{abstract}
The residual estrogenic pollutant alkyl phenols, 4-nonylphenol (NP), 4-tert-octylphenol (OP), and the sex ratio of Formosa landlocked salmon Oncorhynchus formosanus were surveyed in the Formosa landlocked salmon ecological reservation area. This species survives as a remnant, landlocked population in the headwaters of the Chichiawan Stream, a tributary of the Tachia River of central Taiwan. Dams restrict the movement of fish in and out of the agriculturally influenced zones. Fish $(n=157)$ were collected from a total of 9 habitat sites, and the amount of NP and OP present in each site (ambient water from rearing pools, streams, stream sediments, and agricultural effluents) was measured and the sex of the fish was determined via a noninvasive PCR-based method. The results indicate significantly higher NP content and a skewed sex ratio in Formosa landlocked salmon found in agricultural zones compared to salmon found in non-agricultural zones. The concentrations and distributions of NP observed in this study are ecologically significant because they correspond with the skewed sexual ratio and the lower quality and quantity of male salmon sperm observed in previous field investigations. Although the skewed sex ratios are likely a reflection of multiple endocrine disrupting compounds rather than simply NP and OP alone, these results support the contention that exposure of Formosa landlocked salmon to environmentally persistent estrogenic chemicals can have deleterious reproductive consequences.
\end{abstract}

KEY WORDS: Endocrine disruptors $\cdot$ Fish $\cdot$ Reproduction $\cdot$ Habitat $\cdot$ Endangered $\cdot$ Taiwan

\section{INTRODUCTION}

The Formosa landlocked salmon Oncorhynchus formosanus (Jordan et Oshima, 1919) is a Critically Endangered species native to Taiwan. It was once widely distributed in 6 tributary streams: the Chichiawan, Kaoshan, Yousheng, Nanhu, Sakaran, and Hohuan Streams of the upper Tachia River basin (Aoki 1917, Behnke et al. 1962). However, it is now only found upstream of the Tachia River in the Chichiawan and Kaoshan Streams located in Shei-Pa National Park in central Taiwan (Ho \& Gwo 2010, Lin 2010; Fig 1). The estimated population size was 2800 individuals, with $97 \%$ of the fish inhabiting the area between Dams 1 and 3 in the Chichiawan Stream during 2007 (Lin 2010; Fig 1). Degradation and loss of

${ }^{*}$ Corresponding author: gwojc@hotmail.com habitat, pollution, overexploitation, erosion-control dams, natural catastrophes, global warming, typhooninduced flooding, tourism, and inbreeding are alleged to be the principal factors in reducing the habitat and contributing to the endangerment of Formosa landlocked salmon (Gwo et al. 1996, 1999, 2010, Hsu \& Gwo 2010).

The Chichiawan Stream $\left(24^{\circ} 21^{\prime}-24^{\prime} \mathrm{N}, 121^{\circ} 17^{\prime}-\right.$ $19^{\prime} \mathrm{E}$ ), with an elevation of $1720 \mathrm{~m}$, is located at Wuling Farm, on the upper reach of the Tachia River and drains from 3 mountains over $3000 \mathrm{~m}$ in distance (Tao, Chihyu, and Pingtien Mountains; Fig. 1). The Chichiawan watershed includes natural forests, reforested areas, meadows, bare areas, tea plantations, and orchards (Tung et al. 2009). Forests occupy $88.4 \%$ of the watershed; meadows and bare areas

(C) The authors 2016. Open Access under Creative Commons by Attribution Licence. Use, distribution and reproduction are unrestricted. Authors and original publication must be credited. 


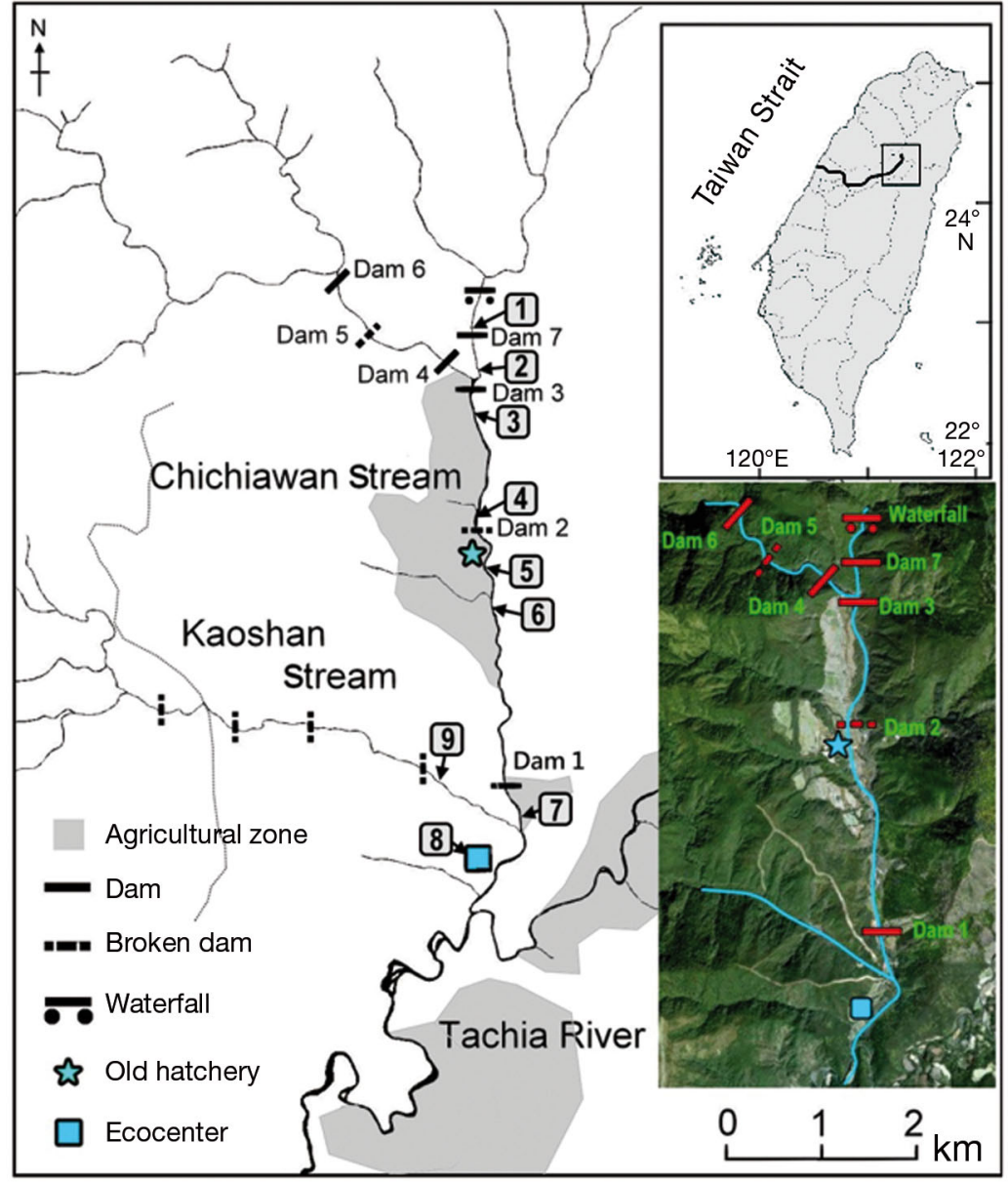

Fig. 1. Sampling sites within the Formosa landlocked salmon ecological reservation area in the upper tributaries of the Tachia River central Taiwan. Site 1: upstream of Chichiawan branch stream-Taoshan North Stream above Dam 7; Site 2: upstream of Chichiawan Stream above Dam 3; Site 3: between Dams 3 and 2; Site 4: agricultural effluent; Site 5: downstream of Dam 2; Site 6: agricultural effluent; Site 7: downstream of Dam 1; Site 8: ecocenter of Taiwan salmon hatchery; Site 9: Kaoshan Stream. Sites 3, 4, 5 and 6 are agricultural zones. Dams 2 and 5 were broken and fish can swim through the dams. Dams 1, 3, 4, 6, and 7 are impassable. Upper inset: enlarged area within Taiwan; black line shows Tachia River

cover $10 \%$; orchards, tea plantations and gardens encompass $1.5 \%$. Most orchards occupy the lower reach of the riparian zone on the west bank, and the cliffs on the east bank are very close to the river channel. The Chichiawan Stream is regarded as a moderately impacted agricultural stream (Lin \& Chang 1989, Shieh \& Yang 2000, Lin 2010). Both the aquatic fauna and benthic algae present in the Chichiawan Stream suggest that the downstream reach of the Chichiawan Stream is eutrophic (Shieh \& Yang 2000, Lin 2010). As one moves downstream, conditions become progressively less suitable for salmon. Water temperatures increase and the water quality deteriorates, exceeding Taiwan EPA (Envi- ronmental Protection Agency) standards for healthy aquatic environments (Shieh \& Yang 2000, Taiwan EPA 2005). The erosion-control dam 2 (Dam 2) broke in the 1990s, allowing fish to swim through the dam. Five other erosioncontrol dams (Dams 1, 3, 4, 6 and 7), $>10 \mathrm{~m}$ in height, in the Chichiawan main stem prevent the salmon from migrating upstream or downstream. The erosion-control dam 1 (Dam 1) of the Chichiawan Stream blocks the movement of Formosa salmon between the Kaoshan and Chichiawan Streams. The Kaoshan Stream $\left(24^{\circ} 21^{\prime}-24^{\circ} 31^{\prime} \mathrm{N}\right.$, $121^{\circ} 20^{\prime}-121^{\circ} 35^{\prime} \mathrm{E}$ ) is a tributary of the Chichiawan Stream at an elevation of $1700-1800 \mathrm{~m}$ and is situated in an upstream reach of the Tachia River, joining the Chichiawan Stream below Dam 1 (Fig. 1). The riparian vegetation is mostly dense virgin forest, free from agricultural development. The area has an overall water quality index of $93.84 \pm$ 2.91 and is considered to have a fine water quality (Lin 2010).

There are ample reports showing the significant destructive effects of endocrine disruptors (EDs) on reproduction in male fish, such as interference with hormone receptor-mediated processes, with normal hormone titres via metabolic and excretory mechanisms, and with gonadal development (Blackburn \& Waldock 1995, Jobling et al. 1996, 1998, Mattiessen 2003, Gregory et al. 2008, Wang et al. 2010). 4-nonylphenol (NP) and 4-tert-octylphenol (OP), 2 degradation products from nonylphenol polyethoxylates (NPEOs), can be found in detergents, pesticides, herbicides, and chemical fertilizers. Their chemical structures are similar to estradiol $\left(\mathrm{E}_{2}\right)$, a potent estrogen. NP and OP are environmentally resistant and persistent chemicals which stimulate biological responses to an extent similar to estradiol itself. However, NP and OP are 1000- to 10000 -fold less effective at stimulating biological responses than the endogenous ligand, $17 \beta$-estradiol (E2), and about a million-fold less effective than $17 \alpha$ ethinylestradiol (EE2) (White et al. 1994). When these chemicals enter the ecological system, the effect of bio-accumulation dramatically increases the concentration of NP and OP in organisms. Due to the 
pseudo-hormonal effects of NP and OP, interference of sexual development and feminization in males can result (Devlin \& Nagahama 2002, Larsson \& Förlin 2002, Lintelmann et al. 2003). Further, NP-induced feminization has been shown to result in intersexual gonads in $37 \%$ of affected amago salmon Oncorhynchus masou ishikawae (Nakamura et al. 2002). However, studies on the occurrence of NP in wild fish or endangered species are limited.

Hsu \& Gwo (2010) developed a simple and noninvasive PCR-based method to identify sex in masu salmon complex species. The phenotypic sex ratios of the populations were estimated with this method. To our knowledge, evaluation of the effects produced by NP and OP in the endangered species population level has not yet been studied. Huang et al. (2010) reported the occurrence of NP and OP in all 10 Formosa landlocked salmon tissue and organs collected from the Formosa landlocked salmon ecological reservation area of Taiwan in 2007. However, no data exists on the sex ratio of the fish populations. This study was conducted to further examine the residual levels of NP and OP in stream water and sediment of the ecological reservation area where Formosa landlocked salmon are found and to investigate the fish sex ratio of the populations collected at those same sites during July 2007. Our hypothesis is that a relationship exists between the concentration of NP and OP in the stream environment and sexual determination in members of the resident Formosan salmon population.

\section{MATERIALS AND METHODS}

\section{Study area and sample collection}

A total of 95 wild individuals of Formosa landlocked salmon of mixed age and sex were sampled randomly using a casting net (Table 1), in both nonagricultural zones (Site 1 and Site 7) and agricultural zones (from Site 2 to Site 6), in the Chichiawan Stream. Formosa landlocked salmon were also sampled from 2 other sites: the Ecocenter Taiwan salmon hatchery (Site 8) and Kaoshan Stream (Site 9) (Fig. 1) using a cast netting method. Salmon from these 2 sites served as reference populations. In other words,
42 cultivated Formosa landlocked salmon reared in the Ecocenter Taiwan salmon hatchery (Site 8) and 20 wild populations collected from the Kaoshan Stream (Site 9) served as reference populations. Water and sediment were taken from 9 sites: 7 sites on the west bank of the Chichiawan Stream, including 2 with agricultural effluent (Sites 4 and 6); 1 in the Kaoshan Stream; and 1 in the Ecocenter Taiwan salmon hatchery (Fig. 1). Water was collected using a stainless steel sampler and poured into a borosilicate amber glass bottle. Surface samples (1-10 cm) of sediment were collected using an Ekman grab sampler (Wildlife Supply Company) and stored in a galvanized iron bottle. Three replicate water samples were collected and shipped to the laboratory in ice-packed containers. Upon their arrival at the laboratory, the samples were immediately adjusted to $\mathrm{pH} 2-3$ by adding concentrated $\mathrm{HCl}$ to prevent microbial degradation and then stored at $4^{\circ} \mathrm{C}$ until analysis. The uppermost 1-2 $\mathrm{cm}$ of the sediment was collected from each grab sample, placed in clean glass jars, transported to the laboratory in coolers with ice, and stored at $-20^{\circ} \mathrm{C}$ until analysis.

The sites selected represent a range with regard to general water quality (from 'very good' to 'poor' according to Taiwan EPA categories). Other necessary criteria for each site included (1) an abundance of fish, (2) the presence of both 'upstream' and 'downstream' sites, and (3) the existence of data on 
the characteristics of water discharge entering the rivers. The mean stream flow velocity at the time of sampling was approximately $0.58 \mathrm{~m} \mathrm{~s}^{-1}$.

\section{Chemical concentration assays}

The NP and OP concentrations in water and sediment samples of Formosa landlocked salmon in the ecological reservation area were pretreated and analyzed according to the methods described in detail by Cheng et al. (2006) and Chen et al. (2012, 2014).

\section{Fish sex ratio}

A total of 157 adipose fin samples were collected (July-August 2007) according to the following fish sampling regime (Table 1). Procedures for sex identification of Formosa landlocked salmon were essentially based on Hsu \& Gwo (2010) and Hsu et al. (2011). Briefly, this assay required 2 primer pairs: OtY2 amplified as a male-specific marker and mtDNA 16S rRNA fragment from Formosa landlocked salmon (NC_008745) amplified as an internal control. The multiplex PCR system allowed assessment of failed reactions versus female individuals and eliminated possible errors associated with reliance on a male-specific marker for sex identification. The positive control ensured that the absence of a male-specific product was not due to PCR failure, which could generate a false-negative result and the assignment of the wrong sex. Genotypic sex was confirmed by at least 3 independent additional PCR reactions for each extraction. Females were identified by the presence of a bright $200 \mathrm{bp}$ band, whereas males had bright bands at 200 and $250 \mathrm{bp}$ for the multiplex PCR reaction assay.

\section{Statistical analyses}

All statistical analyses were conducted with the Statistical Analysis System (SAS Software). Generalized linear models were used to analyze 2-way ANOVA (analysis of variance). Multiple comparisons of NP and OP concentrations in water and sediment from different sites were conducted using Tukey's Honestly Significant Difference test in conjuction with an ANOVA. Sex ratio was tested for equality (female:male $=1: 1$ ) and was calculated for different sites, agricultural, and non-agricultural sections, by using the chi-square goodness-of-fit test at the 0.05 significance level.

\section{RESULTS}

\section{Water and sediment}

The concentrations of the alkyl phenols detected varied between streams and among different sites in the same stream (Figs. $2 \& 3$ ). The concentrations of OP were generally lower than those of NP. The NP and OP levels in the water from non-agricultural

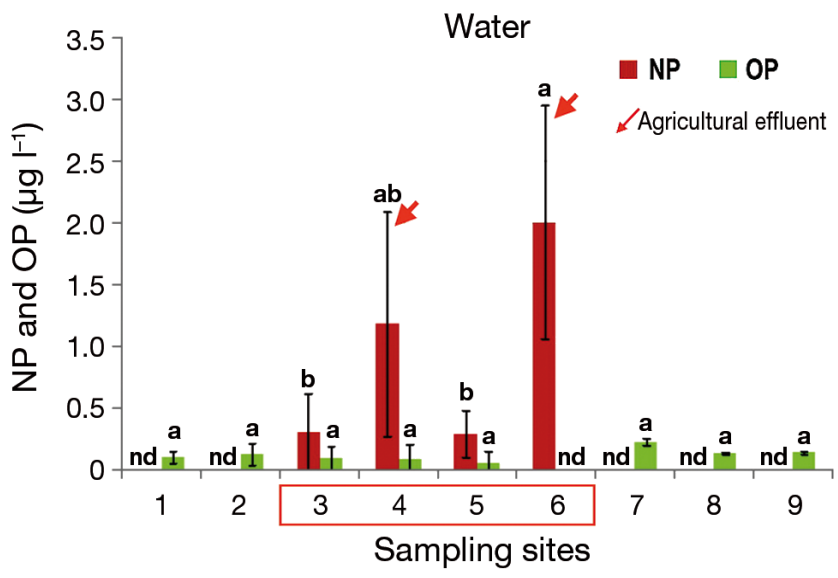

Fig. 2. Concentrations of 4-nonylphenol (NP) and 4-tertoctylphenol (OP) in water of 9 habitat sites (ambient water from rearing pools, streams, stream sediments, and agriculture effluents) within the Formosa landlocked salmon ecological reservation area. See Fig. 1 for site descriptions. Sites $3,4,5$ and 6 (in red box) are agricultural zones. Values are means \pm SD. $\mathrm{n}=5$ in all experiments. Values with different letters differ significantly $(p<0.05)$. nd: non-detectable

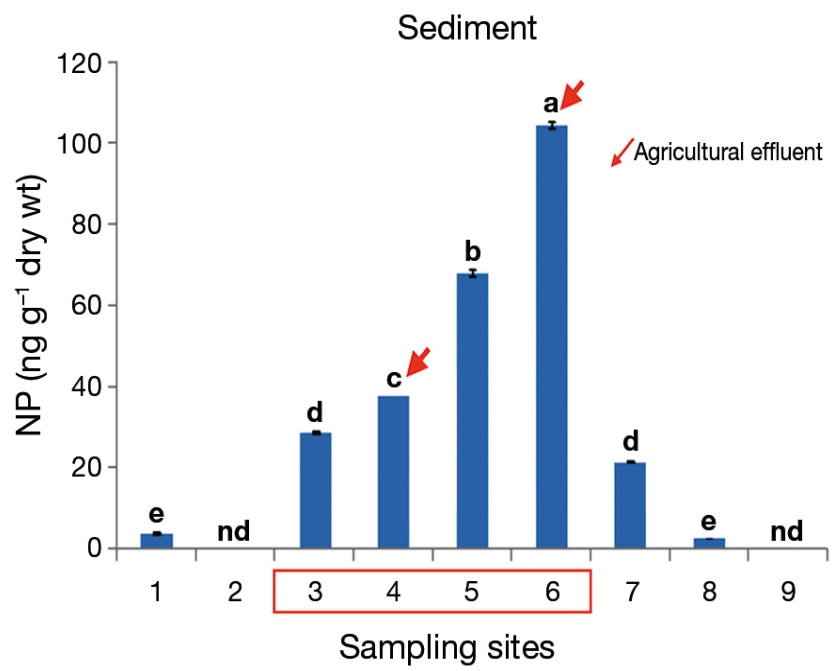

Fig. 3. Concentrations of 4-nonylphenol (NP) in sediment of 9 habitat sites within the Formosa landlocked salmon ecological reservation area. See Fig. 1 for site descriptions. Sites $3,4,5$ and 6 (in red box) are agricultural zones. Values are means \pm SD. $n=5$ in all experiments. Values with different letters differ significantly $(\mathrm{p}<0.05)$. nd: non-detectable 
zones (Sites 1, 2, 7, 8 \& 9) of the Chichiawan Stream were non-detectable and low (from 101 to $224 \mathrm{ng} \mathrm{l}^{-1}$ ), respectively, while in the water from the agricultural zone (Sites 3, 4, 5 \& 6), NP levels were high but varied from $289 \mathrm{ng} \mathrm{l}^{-1}$ (Site 3) to $2007 \mathrm{ng} \mathrm{l}^{-1}$ (Site 6), while the OP content was low (from non-detectable, i.e. $<16 \mathrm{ng}^{-1}$, to $101 \mathrm{ng} \mathrm{l}^{-1}$; Fig. 2). These results indicated that OP content in water samples was low (Fig. 2) and non-detectable $\left(<16 \mathrm{ng} \mathrm{g}^{-1}\right)$ in all sampled stream sediments (Fig. 3). In contrast, NP content was detectable in all water samples from the agricultural zone (from $289 \pm 191 \mathrm{ng} \mathrm{l}^{-1}$ to $2007 \pm 946 \mathrm{ng} \mathrm{l}^{-1}$; Fig. 2) and in almost all stream sediment samples (Fig. 3). In particular, NP levels were the highest at Site 6 , a site strongly affected by effluent from the agricultural zone, located in the middle reach of the Chichiawan Stream (Figs. 2 \& 3). The average OP levels in all sediment samples (agricultural and nonagricultural zones) were below the detectable level $\left(<5.4 \mathrm{ng} \mathrm{g}^{-1}, \mathrm{n}=5\right)$. The average NP levels in stream sediment samples were much higher around the agricultural area (from Sites 3 to 6, between Dams 3 and 1, the mainstream of the Chichiawan Stream) than at any other sites (Sites 1, 2, 7, 8, \& 9; Fig. 3).

\section{Fish}

The female to male sex ratios of Formosa landlocked salmon evaluated from each site are given in Table 1. Of the 157 fish screened, 93 (59\%) were found to be female. Populations from stream segments located in the agricultural zone had higher frequencies of females (between Dams $3 \& 2,73 \%$; and between Dams $2 \& 1,68 \%$ ) than the 4 reference populations in non-agricultural zones (upstream of the Chichiawan Stream above Dam 3, $59 \%$; downstream of the Chichiawan Stream below Dam 1, 58\%; from the Kaoshan Stream, $40 \%$; and from the Ecocenter Taiwan salmon hatchery, 52\%). The chi-square showed a significant skew in the average sex ratio (female:male $=2.29: 1$ ) for the fish we caught in the agricultural zone (Table 1). The sex ratio (39 female:17 male) is significantly ( $p=0.008$; significance level: $p<0.05$ ) skewed towards females in the agricultural zone but not in the non-agricultural zone (54 female:47 male).

\section{DISCUSSION}

Wang et al. (2002) investigated NP levels in the water and sediments of 40 rivers in Taiwan. Approxi- mately $54.2 \%$ of the rivers were positive for NP; the mean content was $4870 \mathrm{ng} \mathrm{l}^{-1}$, and the range was from 890 to $50000 \mathrm{ng} \mathrm{l}^{-1}$. Cheng et al. (2006) monitored the levels of NP in 18 of Taiwan's major rivers and found that NP was detected in $100 \%$ (all) water samples and the average NP concentrations ranged from non-detectable to $5100 \mathrm{ng} \mathrm{l}^{-1}$ and were lower than in the survey by Wang et al. (2002). However, both studies only investigated lower altitude rivers (below $200 \mathrm{~m}$ ) of the reservation area. Because the altitude of the Chichiawan Stream is about $1720 \mathrm{~m}$, this report is the first to deal with the ED content of a higher altitude river in Taiwan.

NP and OP are synthetic compounds that do not occur naturally, and therefore environmental concentrations of NP and OP in the Formosa landlocked salmon ecological reservation area must be solely attributed to human activity. Many forests in the upper Tachia River watershed were converted into agricultural land for vegetables, tea and orchards starting in the 1960s (Lin 2010). Agriculture is the most important source of nutrients in nonpoint source discharge, supplying about $26 \%$ of the total nitrogen and $32 \%$ of the orth-phosphorous in 2004, even though Subwatershed A only covers $19 \%$ of the area of the Wuling catchment (Chang et al. 2008, Lin 2010). The agricultural Subwatershed A exports higher nutrients per unit area than other forest subwatersheds (Lin 2010). The high NP levels observed at Sites 4 and 6 are likely due to the mass use of fertilizer and pesticides for cabbage crops (the major vegetation in the area) and orchards, leading to higher NP levels in effluent waters and sediments. The concentrations of OP in the sediment were generally lower than those of NP at the same sites. The concentrations in water reflected the current pollution levels, but the concentrations in sediment showed long-term discharge of effluent resulting in accumulation of less degradable chemicals in the environment.

Although both NP and OP levels in the water samples from the Formosa landlocked salmon ecological reservation area were much lower than the concentrations observed to induce vitellogenesis in male rainbow trout Oncorhynchus mykiss and amago salmon (Jobling et al. 1996, Ackermann et al. 2002, Nakamura et al. 2002, Jobling \& Tyler 2003), the induction of both masculinization and feminization of aquatic organisms by NP has been reported over the past decade, including in recent studies (Gregory et al. 2008, Soares et al. 2008, Chen et al. 2012, 2014). Clearly, NP affects a large range of species which 
occupy different trophic levels of the food chain in both freshwater and marine environments. The biodegradation rate of NP is low, and it can easily accumulate in sediments of the receiving waters downstream of pollution effluents and is readily taken up by fish and aquatic invertebrates either through the gill or from benthic organisms they consume (Zou 2003, Soares et al. 2008, Mao et al. 2012). Because NP is both lipophilic and resistant to biodegradation, it can accumulate in a variety of fish tissues with a bioconcentration factor (BCF) from 0.9 to 35589 (Mills \& Chichester 2005, Soares et al. 2008). Chen et al. (2014) found that the concentrations of NP in the livers of wild tilapia (Orechromis mossambicus and O. niloticus) from the Dan-Shui River in Taiwan were higher than in muscle. The bioaccumulation factors (BAFs) of NP were 679 in muscle, 4697 in liver and 8895 in gonad. Apparently, gonads are the target organ of reproductive toxicity. The BCF of nonylphenol in fathead minnows Pimephales promelas was 245-380 after $42 \mathrm{~d}$ of nonylphenol exposure in a flow-through system in which the concentration of nonylphenol was $0.33-2.36 \mu \mathrm{g} \mathrm{l}^{-1}$, indicating that long-term exposure at even low concentrations can lead to accumulation in the fish (Snyder et al. 2001).

The significant female-skewed sex ratio of Formosa landlocked salmon in the agricultural zone (Site 4 and Site 6) was observed in the present study. Several investigations have demonstrated that the effect of 2 or more compounds with endocrine disruption capacity, even at low concentrations, can be additive or synergistic (Silva et al. 2002, TenEyck \& Markee 2007, Soares et al. 2008). Although each chemical separately might represent a low level risk, their combined toxicity might increase the overall ecotoxicological effects. TenEyck \& Markee (2007) demonstrated that combinations of NP, NP1EO, and NP2EO produce adverse effects on exposed fathead minnow due to additive or synergistic effects. Synergistic effects of mixtures of estrogenic compounds on the induction of vitellogenesis in male or juvenile fishes have been described (Hiramatsu et al. 2005, TenEyck \& Markee 2007, Soares et al. 2008). Various pesticides, applied 12 to 18 times a year, were used at the Wuling Farm (Lin \& Chang 1989, Lin 2010).

The present study had some limitations. Because Formosa landlocked salmon is a Critically Endangered species, fish sample size is limited, it is not possible to perform exposure experiments to directly confirm the impacts of suspected chemicals on the fish reproductive features and sex ratio, and thus information on their exposure before or during sex differentiation is absent; this might reduce the strength of correlation between skewed sex ratios and NP concentrations. The reliability of sex identification using our PCR-based method was 98.40\% ( $1.60 \%$ mismatch or 2 mismatches in 125 individuals) for Formosa landlocked salmon (Hsu \& Gwo 2010). Although there are no reports in nature of spontaneous sex-reversed individuals in the highly inbred Formosa landlocked salmon and the Oncorhynchus masou complex, we presume that the low frequency $(1.60 \%)$ of sex-reversed fish in Formosa landlocked salmon may be due to environmental influence rather than to DNA recombination (Hsu \& Gwo 2010). Also, our sex identification method is unable to determine phenotypic sex that can be reversed by chemical compounds.

Huang et al. (2010) found NP distributed in the organs and tissues of Formosa landlocked salmon. Higher NP content was observed in the liver when compared to NP content observed in muscle. They further detected an NP concentration (98.75 $\mathrm{ng} \mathrm{g}^{-1}$ ), a $\mathrm{BCF}$ of 330 , in the livers of Formosa landlocked salmon, concentrations comparable with those of riparian pinophyta tree leaves $\left(126.37 \mathrm{ng} \mathrm{g}^{-1}\right.$ ) in the Formosa landlocked salmon ecological reservation area (Lu et al. 2007). In reality, Formosa landlocked salmon are exposed to a spectrum of various kinds of estrogenic chemicals rather than to any single EDs in polluted aquatic environments, because the total area of cultivated land was nearly 5000 ha in 1980, and at least 16 to 195 kinds of pesticides, applied 12 to 18 times a year, were used at the Wuling Farm (Lin \& Chang 1989; Lin 2010). The decline in the sex ratio and reproductive ability in male Formosa landlocked salmon reported by Huang et al. (2010) is likely related to the prevalence of a combination of various EDs in their habitat rather than simply to NP and OP alone.

In conclusion, there is clearly a need for continued research into the effects, even at low concentrations, of synthetic chemicals in the environment. Although unlikely to be the sole cause of the failing recruitment or decreased abundance of Formosa landlocked salmon, as a result of the precautionary principle, endocrine disruption may subtly sabotage sexual development, sex ratio, and metabolic compensation for environmental stress. This likely will not extirpate a species over its entire range, but in combination with other stressors (e.g. inbreeding, a small population, habitat loss and fragmentation, overfishing, pollution, and global climate change) endocrine disruption may contribute to the extinction of Formosa landlocked salmon (Melbourne \& Hastings 2008). 
Acknowledgements. The work was supported by Shei-Pa National Park, Ministry of the Interior, Taiwan and National Science Council, Taiwan (NSC) under project number 982311-B-019-003-MY3 to J.-C. Gwo.

\section{LITERATURE CITED}

Ackermann GE, Schwaiger J, Negele RD, Fent K (2002) Effects of long-term nonylphenol exposure on gonadal development and biomarkers of estrogenicity in juvenile rainbow trout (Oncorhynchus mykiss). Aquat Toxicol 60: 203-221

Aoki T (1917) One kind of salmon lives in Taiwan. Fish Res 12:305-306

Behnke RJ, Koh TP, Needham PR (1962) Status of the landlocked salmonid fishes of Formosa with a review of Oncorhynchus masou (Brevoort). Copeia 1962(2):400-407

Blackburn MA, Waldock MJ (1995) Concentrations of alkylphenola in rivers and estuaries in England and Wales. Water Res 29:1623-1629

> Chang CL, Kuan WH, Lui PS, Hu CY (2008) Relationship between landscape characteristics and surface water quality. Environ Monit Assess 147:57-64

Chen WL, Wang GS, Gwo JC, Chen CY (2012) Ultra-high performance liquid chromatography/tandem mass spectrometry determination of feminizing chemicals in river water; sediment and tissue pretreated using disk-type solid-phase extraction and matrix solid-phase dispersion. Talanta 89:237-245

> Chen WL, Gwo JC, Wang GS, Chen CY (2014) Distribution of feminizing compounds in the aquatic environment and bioaccumulation in wild tilapia tissues. Environ Sci Pollut Res Int 21:11349-11360

> Cheng CY, Wu CY, Wang CH, Ding WH (2006) Determination and distribution characteristics of degradation products of nonylphenol polyethoxylates in the rivers of Taiwan. Chemosphere 65:2275-2281

Devlin RH, Nagahama Y (2002) Sex determination and sex differentiation in fish: an overview of genetic, physiological, and environmental influences. Aquaculture 208:191-364

Gregory M, Aravindakshan J, Nadzialek S, Cyr DG (2008) Effects of endocrine disrupting chemicals on testicular functions. In: Alavi SM, Cosson JJ, Coward K, Rafiee GH (eds) Fish spermatology. Alpha Science International, Oxford, p 161-214

Gwo JC, Lin XW, Gwo HH, Wu HC, Lin PW (1996) The ultrastructure of Formosan landlocked salmon, Oncorhynchus masou formosanus, spermatozoon (Teleostei; Salmoniformes; Salmonidae). J Submicrosc Cytol Pathol 28:33-40

Gwo JC, Ohta H, Okuzawa K, Wu HC, Lin PW (1999) Cryopreservation of fish sperm from the endangered Formosan landlocked salmon (Oncorhynchus masou formosanus). Theriogenology 51:569-582

Gwo JC, Shen MW, Cheng HY (2010): Formosa landlocked salmon and masu salmon monograph. Familysky, Taichuan (in Chinese)

Hiramatsu N, Cheek AO, Sullivan CV, Matsubara T, Hara A (2005) Vitellogenesis and endocrine disruption. Environ Toxicol 6:431-471

Ho HC, Gwo JC (2010) Salmo formosanus Jordan \& Oshima, 1919 (currently Oncorhynchus formosanus) (Pisces, Salmonidae, Salmoninae): proposed conservation of the specific name. Bull Zool Nomencl 67:300-302
Hsu TH, Gwo JC (2010) A PCR-based method for sex identification of Critically Endangered Formosa landlocked salmon. Fish Sci 76:613-618

> Hsu TH, Adiputra YT, Ohta H, Gwo JC (2011) Species and sex identification of Formosa landlocked salmon using loop-mediated isothermal amplification. Mol Ecol Resour 11:802-807

Huang YS, Chen ML, Chou CC, Gwo JC (2010) What inhibits the testicular development in Formosan landlocked salmon (Oncorhynchus masou formosanus)? J Nat Taiwan Mus Spec Publ Ser 14:123-134

Jobling S, Tyler CR (2003) Endocrine disurption in wild freshwater fish. Pure Appl Chem 75:2219-2234

Jobling S, Sheahan D, Osborne JA, Matthiessen P, Sumpte JP (1996) Inhibition or testicular growth in rainbow trout (Oncorhynchus mykiss) exposed to estrogenic alkylphenolic chemicals. Environ Toxicol Chem 15:194-202

> Jobling S, Nolan M, Tyler CR, Brighty G, Sumpter JP (1998) Widespread sexual disruption in wild fish. Environ Sci Technol 32:2498-2506

> Larsson DGJ, Förlin L (2002) Male-biased sex ratios of fish embryos near a pulp mill: temporary recovery after a shortterm shutdown. Environ Health Perspect 110:739-742

Lin HJ (2010) Long-term ecological monitoring and ecosystem modeling in the Wulin area. Technical report, SheiPa National Park Adminstration, Taichung (in Chinese)

Lin YS, Chang KH (1989) Conservation of the Formosan landlocked salmon Oncorhynchus masou formosanus in Taiwan, a historical review. Physiol Ecol Jpn Spec 1: $647-652$

Lintelmann J, Katayama A, Kurihara N, Shore L, Wenzel A (2003) Endocrine disruptors in the environment. Pure Appl Chem 75:631-681

Lu YY, Chen ML, Sung FC, Wang PS, Mao IF (2007) Daily intake of 4-nonylphenol in Taiwanese. Environ Int 33: 903-910

Mao Z, Zheng XF, Zhang YQ, Tao XX, Li Y, Wang W (2012) Occurrence and biodegradation of nonylphenol in the environment. Int J Mol Sci 13:491-505

Mattiessen P (2003) Endocrine disruption in marine fish. Pure Appl Chem 75:2249-2261

Melbourne BA, Hastings A (2008) Extinction risk depends strongly on factors contributing to stochasticity. Nature 454:100-103

> Mills LJ, Chichester C (2005) Review of evidence: Are endocrine-disrupting chemicals in the aquatic environment impacting fish populations? Sci Total Environ 343:1-34

> Nakamura M, Nagoya H, Hirai T (2002) Nonylphenol complete feminization of the gonad in genetically controlled all-male amago salmon. Fish Sci 68:1387-1389

Shieh SH, Yang PS (2000) Community structure and functional organization of aquatic insects in an agricultural mountain stream of Taiwan: 1985-1986 and 1995-1996. Zool Stud 39:191-202

> Silva E, Rajapakse N, Kortenkamp A (2002) Something from 'nothing' - eight weak estrogenic chemicals combined at concentrations below NOECs produce significant mixture effects. Environ Sci Technol 36:1751-1756

Snyder SA, Keith TL, Pierens SL, Snyder EM, Giesy JP (2001) Bioconcentration of nonylphenol in fathead minnows (Pimephales promelas). Chemosphere 44:1697-1702

Soares A, Guieysse B, Jefferson B, Cartmell E, Lester JN (2008) Nonylphenol in the environment: a critical review on occurrence, fate, toxicity and treatment in wastewaters. Environ Int 34:1033-1049 
Taiwan EPA (2005) Standard guide for conducting acute tests: static renewal test for neocaridina denticulate (NIEA B905.11B). Taiwan Environmental Protection Administration, Executive Yuan, Taipei (in Chinese)

TenEyck MC, Markee AP (2007) Toxicity of nonylphenol, nonylphenol monoethoxylate, and nonylphenol diethoxylate and mixtures of these compounds to Pimephales promelas (fathead minnow) and Ceriodaphnia dubia. Arch Environ Contam Toxicol 53:599-606

Tung C, Lee TY, Yang TCE, Chen YJ (2009) Application of genetic programming to project climate change impacts on the population of Formosan landlocked salmon. Environ Model Softw 24:1062-1072

Editorial responsibility: Steven Cooke, Ottawa, Ontario, Canada
Wang CH, Chang SP, Huang RK, Lee YH, Wang SK, Hung WT, Chen PS (2002) Residues survey of nonylphenol and its biological effect on male carp. Ann Rep NIEA Taiwan ROC 9:291-312 (in Chinese with English Abstract)

Wang J, Shim WJ, Yim UH, Kannan N, Li D (2010) Nonylphenol in bivalves and sediments in the northeast coast of China. J Environ Sci (China) 22:1735-1740

White R, Jobling S, Hoare SA, Sumpter JP, Parker MG (1994) Environmentally persistent alkylphenolic compounds are estrogenic. Endocrinology 135:175-182

Zou E (2003) Current status of environmental endocrine disruption in selected aquatic invertebrates. Acta Zool Sin 49:551-565

Submitted: May 4, 2015; Accepted: December 17, 2015 Proofs received from author(s): February 10, 2016 